\title{
Prevalence of multiple sclerosis in Goiânia, Goiás, Brazil
}

\author{
Prevalência de esclerose múltipla em Goiânia, Goiás, Brasil \\ Taysa Alexandrino Gonsalves Jubé RIBEIRO', Aline Leite DUARTE², Delson José da SILVA ${ }^{3,4,5}$, Fernando \\ Elias BORGES ${ }^{5}$, Vanessa Maia da COSTA², Regina Maria PAPAIS-ALVARENGA ${ }^{1,6}$, Denise Sisterolli DINIZ1
}

\begin{abstract}
Multiple sclerosis (MS) prevalence, in some cities in Brazil, was estimated and was found to range from 0.75 to 30.7/100,000. The reasons for such a large variation in rates of prevalence are not clear, but environment and genetics help to explain this phenomenon. Methods: A crosssectional study using three sources of case ascertainment to estimate the prevalence of MS in the city of Goiânia in December, 2015. Results: A total of 318 MS patients was found after removing overlapping sources. The prevalence of MS was 22.4/100,000 population. Conclusion: Our study was the first in Goiás and the third in the midwest region, and we found a great increase in the prevalence of MS in the region. It is necessary to perform other studies using the same methodology for a more accurate evaluation of the true prevalence of MS in Brazil.
\end{abstract}

Keywords: Prevalence; multiple sclerosis; neuroogy.

\section{RESUMO}

A prevalência de esclerose múltipla (EM) no Brasil foi estimada em algumas cidades e foi encontrada entre 0,75 e 30,7 / 100.000. As razões para tal grande variação nas taxas de prevalência não são claras, mas existem aspectos ambientais e genéticos para explicar esse fenômeno. Métodos: Foram utilizadas três fontes de averiguação de casos para estimar a prevalência de esclerose múltipla (EM) no município de Goiânia em dezembro de 2015. Resultados: Foram encontrados 318 casos de EM, retirando as sobreposições de fontes. A prevalência foi de 22,4 / 100.000. Conclusão: Nosso estudo foi o primeiro em Goiás e o terceiro na Região Centro-Oeste, e encontrou um grande aumento na prevalência de EM na região. É necessário realizar outros estudos utilizando a mesma metodologia para uma melhor avaliação da real prevalência da EM no Brasil.

Palavras-chave: Prevalência; esclerose múltipla; neurologia.

Multiple sclerosis (MS) is an inflammatory, demyelinating and degenerative disease of the central nervous system, of unknown etiology but supposedly associated with the interaction of genetic, infectious and environmental factors, more often affecting young adults, Caucasians and females. The disease is characterized by repeated episodes of neurological symptoms affecting several parts of the central nervous system, called functional systems, resulting in a great variability of symptoms, which typically include cognitive, sensory and motor alterations ${ }^{1}$. The prevalence of MS varies considerably worldwide. Kurtzke has designated a three-zone global prevalence rating: high (30-80 per 100,000), medium (5-25 per 100,000), and low zones $(<5 \text { per } 100,000)^{2}$. Wade, in 2013, proposed a new global MS prevalence scale with five categories: very high (170-350 per 100,000), high (70-170 per 100,000), medium (38-70 per 100,000$)$, low (13-38 per 100,000$)$, and very low $(0-13 \text { per } 100,000)^{3}$. It was estimated that Brazil was in the

\footnotetext{
${ }^{1}$ Universidade Federal de Goiás, Faculdade de Medicina, Disciplina de Neurologia, Goiânia, GO, Brasil;

${ }^{2}$ Instituto de Neurologia de Goiânia, Departamento de Neurologia , Goiânia, GO, Brasil;

${ }^{3}$ Instituto Integrado de Neurociências, Departamento de Neurociências, Goiânia, GO, Brasil;

${ }^{4}$ Hospital das Clínicas de Goiânia, Departamento de Neurociências, Goiânia, GO, Brasil;

${ }^{5}$ Hospital Geral de Goiânia, Residência Médica de Neurologia, Ambulatório de Doenças Desmielinizantes, Goiânia, GO, Brasil;

${ }^{6}$ Universidade Federal do Estado do Rio de Janeiro, Neurologia, Rio de Janeiro, RJ, Brasil.

Taysa Ribeiro (iD http://orcid.org/0000-0001-8202-8856; Aline Duarte iD https://orcid.org/0000-0003-3537-0047; Delson José da Silva https://orcid.org/0000-0002-1558-6943; Fernado Elias Borges iD https://orcid.org/0000-0001-7668-0434; Vanessa Maia Costa iD https://orcid.org/0000-0002-6125-5694; Regina Alvarenga (iD) https://orcid.org/0000-0002-1141-8619; Denise Sisterolii Diniz (iD) https://orcid.org/0000-0002-3078-6804

Correspondence: Taysa Alexandrino Gonsalves Jubé Ribeiro; Universidade Federal de Goiás - Clínica Médica; Rua B17, Quadra 10b, lote 18; $74885-642$ Goiânia GO, Brasil; E-mail: tagjr@uol.com.br

Conflict of interest: There is no conflict of interest to declare.
}

Received 20 September 2018; Received in final form 01 January 2019; Accepted 10 January 2019. 

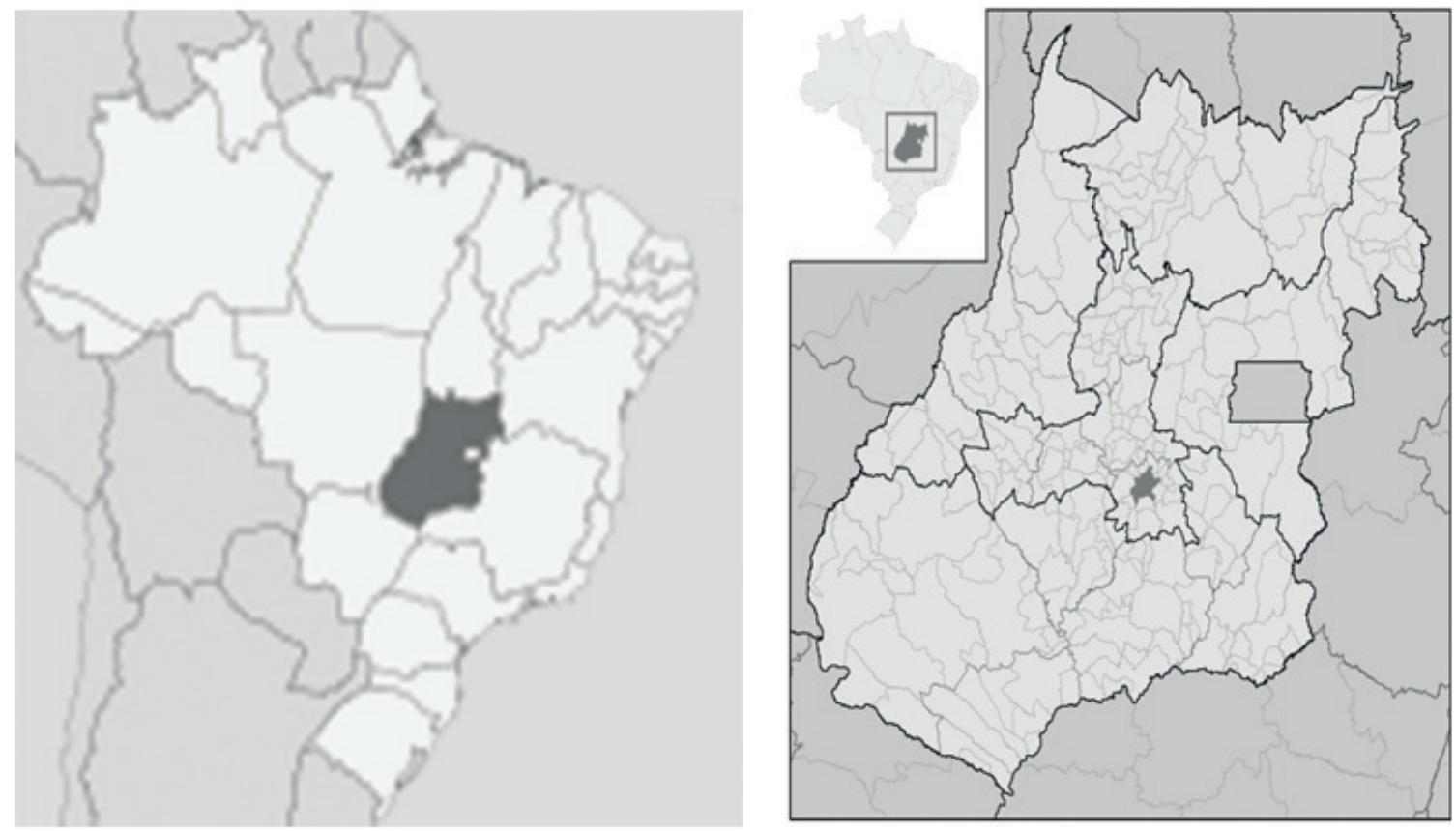

Figure 1. Location of Goiânia in the state of Goiás, Brazil ${ }^{8}$.

medium zone by Kurtzke, and in the low zone by Wade., ${ }^{2,3}$ Brazil is a country covering a very large area, located between latitudes $5^{\circ} 16^{\prime} 20^{\prime \prime} \mathrm{N}$ and $33^{\circ} 44^{\prime} 42^{\prime \prime} \mathrm{S}$, and with five geographic regions: north, south, midwest, southeast and northeast, with widely diversified geographic, demographic and population aspects between the regions. The crude prevalence rates of MS found in studies conducted in Brazil ranged from 1.36/100,000 inhabitants in Recife (northwest region) $)^{5}$ to $27.2 / 100,000$ inhabitants in the city of Santa Maria, Rio Grande do Sul (south region) ${ }^{6}$. The only study that used the capture-recapture method was conducted in Volta Redonda, Rio de Janeiro (southwest region), and found 30.7/100,000 inhabitants, the highest prevalence in Brazil ${ }^{7}$. The aim of the present study was to determine the prevalence of MS in Goiânia, a city located in the midwest region of Brazil, using multiple sources of case ascertainment.

\section{METHODS}

\section{Study site}

Goiânia is capital of the state of Goiás, located in the midwest region. It is in the heart of Brazil, $209 \mathrm{~km}$ from the federal capital, Brasília, and is almost equidistant from all other Brazilian $\operatorname{states}^{8}$ (Figure 1). It is the second most populous city in the midwest region, being surpassed only by Brasília. Its estimated population was 1,430,697 inhabitants in 2015. Goiânia is the sixth largest city in Brazil, covering an area of $728.8 \mathrm{~km}^{2}$, lying near the parallel $16^{\circ} 40^{\prime} 43^{\prime \prime}$ south and the meridian $49^{\circ} 15^{\prime} 14^{\prime \prime}$ west. The Municipal Human Development Index in Goiânia is 0.832, which is considered to be high by the United Nations Development Program. The

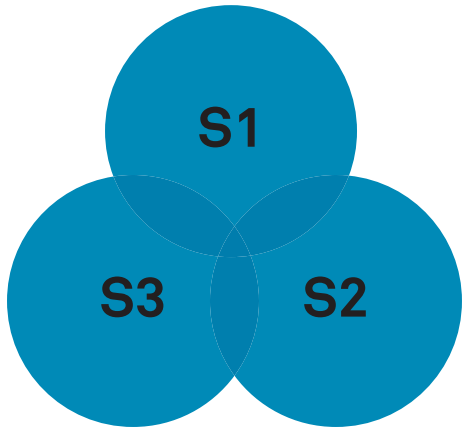

Figure 2. Venn diagram with three sources to gather information on MS patient prevalence. S1 - Dispensing center of high-cost medication, S2 - Centers of reference in the treatment of patients with MS (Hospital das Clínicas/Hospital Geral de Goiânia), S3 - Private neurologists.

longevity index is 0.751 (the overall Brazilian index is 0.638). Goiânia is a multiracial city, having a mixed population, comprising white (48\%), brown (44\%), black (5.68\%), indigenous $(0.16 \%)$ and yellow $(1.68 \%)$ people $e^{4,8}$.

The day of MS prevalence determination was December 31, 2015.

\section{Ethics}

The study was approved by the committee of ethics and research. CAAE: 59067616.2.0000.5083.

\section{Ascertainment of cases of MS}

The tracking was conducted via three sources (Figure 2).

Patients were screened through the International Code of Diseases (ICD 10): G35. A basic questionnaire for the standardized collection of data was prepared. All data were 


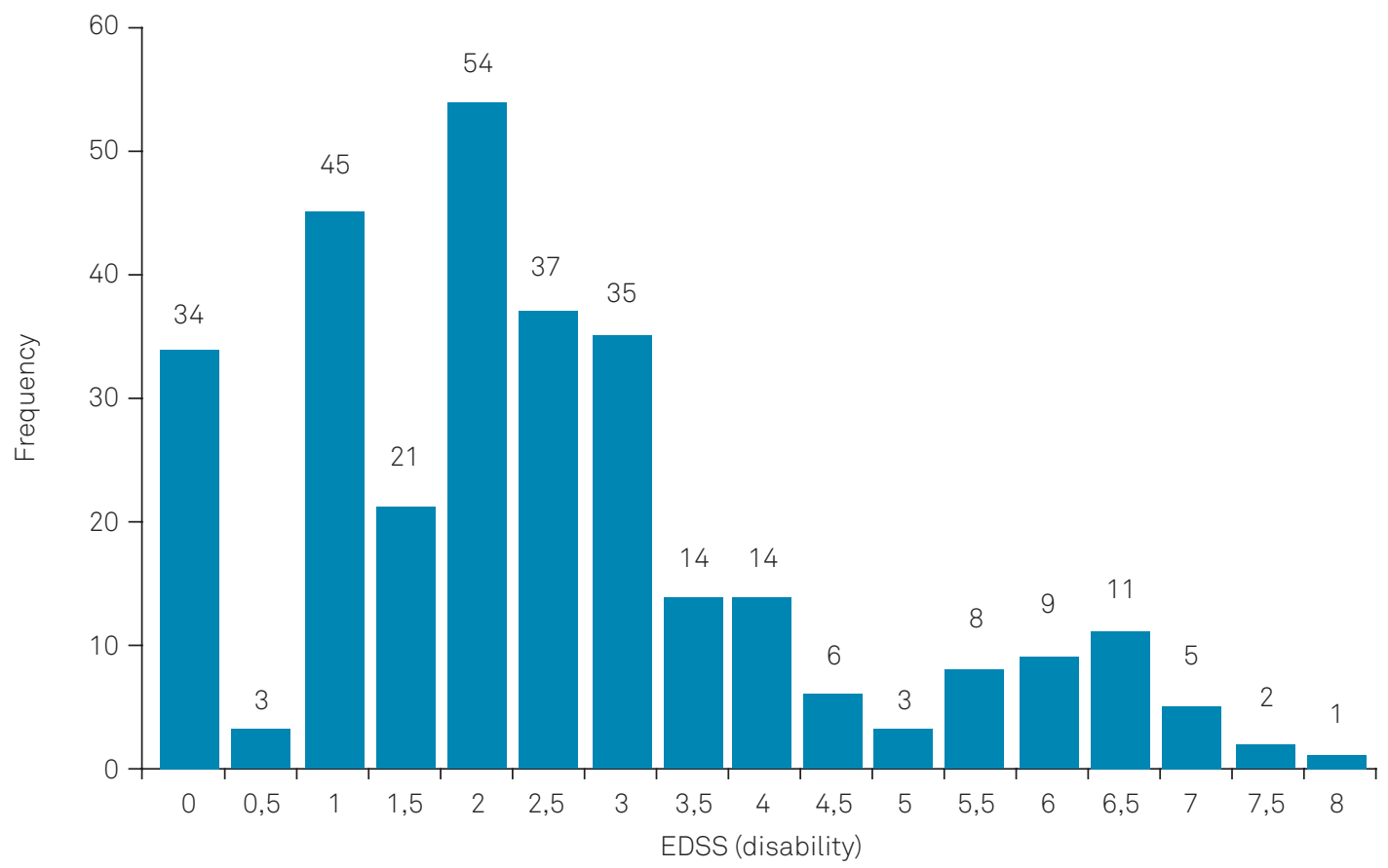

Figure 3. Year of diagnosis.

collected from medical records, and the informed consent form was dispensed with. All patients were alive on December 31, 2015, the day of the prevalence study.

\section{Classifications and definitions}

The MS had been previously diagnosed by the attending physician of each patient. To be included in the study, all diagnoses of MS must had been defined with the Poser diagnostic criteria $^{9}$ and/or the McDonald criteria ${ }^{1}$ and the patients had to reside in the city of Goiânia.

\section{Data analysis}

Crude prevalence was calculated as the number of MS patients divided by the total number of individuals living in Goiânia in Decer, 2015. An analysis of simple linear Spearman's correlation for quantitative variables was performed. Analyses were performed using the SPSS software, version 25.0 for Windows ${ }^{10}$.

\section{RESULTS}

According to the latest demographic census carried out in Brazil in 2010, the population of Goiânia was 1,302,001 inhabitants, of whom 681,144 were women and 620,857 were men. By 2015, the estimated population was $1,430,697^{8,11}$.

The study found 318 cases of people with MS residing in Goiânia on the day of the prevalence study (12/31/2015), representing a crude prevalence of 22.2/100,000 inhabitants. The distribution of patients with MS according to socio-demographic factors and clinical characteristics are described in Figure 3 and Table 1.
Table 1. Clinical and demographic characteristics of patients diagnosed with MS in the city of Goiânia, 2015.

\begin{tabular}{lcc}
\hline Clinical and demographic characteristics of patients & $f$ & $\%$ \\
\hline Sex & 74 & 23,3 \\
\hline Male & 244 & 76,7 \\
\hline Female & 318 & 100,0 \\
\hline Total & & \\
\hline Ethnicity (self-reported) & 230 & 72.3 \\
\hline White & 67 & 21.6 \\
\hline African & 21 & 6.60 \\
\hline No information & 297 & 100.0 \\
\hline Total & & \\
\hline Clinical form & 276 & 86.2 \\
\hline Relapsing-remitting (RRMS) & 27 & 8.5 \\
\hline Secondary progressive (SPMS) & 1 & 0.9 \\
\hline Primary progressive (PPMS) & 14 & 4.4 \\
\hline No information & 304 & 100.0 \\
\hline Total & & \\
\hline Source 1 - Drug dispensing pharmacy & 69 & 21,7 \\
\hline No & 249 & 78,3 \\
\hline Yes & 318 & 100,0 \\
\hline Total & & \\
\hline Source 2 - Reference centers for MS treatment & 233 & 73,3 \\
\hline No & 85 & 26,7 \\
\hline Yes & 318 & 100,0 \\
\hline Total & 217 & 68,2 \\
\hline Source 3 - Neurologists & 101 & 31,8 \\
\hline No & 318 & 100,0 \\
\hline Yes & 103 & 32,4 \\
\hline Total & 91 & 28,6 \\
\hline Degree of disability & 80 & 25,2 \\
\hline No disability & 8,8 \\
\hline Mild disability & & \\
\hline Moderate disability & & \\
\hline Severe disability & & \\
\hline
\end{tabular}


It is important to emphasize the limitations of the study, especially the fact that it was a retrospective study.

\section{DISCUSSION}

In the city of Goiânia, the prevalence of MS was 22.2/100,000, on December 31, 2015. In a literature review ${ }^{11}$ evaluating the MS prevalence in Brazil as a whole, 19 studies were found, out of which 13 studies were carried out in cities in the southeast $12,13,14,15,16,17,18,19,20,21,22,23,24$, two in the southern region $^{6,25}$, two in the midwest ${ }^{26,27}$ and one in the northeast ${ }^{5}$.

Great variability was found in the values of maximum and minimum prevalence rates in the prevalence studies conducted in the country. There was an overall prevalence of 8.69 (95\%CI 6.0-12.6) per 100,000 inhabitants. Regarding the methodologies employed, all the Brazilian studies adopted a cross-sectional design, using raw data from sources such as hospitals, information from neurologists, MRI services, patients' associations, reference centers and high-cost pharmacies. What did vary in these studies was the number of sources used by each author.

Most authors used more than one source for the data collection. Brazil covers a large area, which diversifies geographic, demographic and historical aspects of the regions and the Brazilian population.

In the midwest region there were only two studies of MS prevalence. The first study was conducted in Brasília, Federal District, from 1999 to 2003, and the authors found a prevalence of $5.85 / 100,000^{26}$. The second study was undertaken in the western region, in the city of Cuiabá, Mato Grosso, and showed a prevalence of 4.41/100,000 in 2002 27 .

The methodology was similar in our study and the Cuiabá study (information from various sources). There was no difference in the studies in Brasília, Cuiabá and Goiânia for sex
Table 2. Clinical and demographic characteristics of patients with MS in the midwest region, Brazil (\%).

\begin{tabular}{lccc}
\hline Varialble & Brasília & Cuiabá & Goiânia \\
\hline Female sex & 77.5 & 74.0 & 76.7 \\
White ethnicity & 75.7 & 74.0 & 72.3 \\
Clinical form & & & \\
$\quad$ Relapsing-remitting & 90.6 & 69.5 & 86.2 \\
$\quad$ Secondary progressive & 4.6 & 21.7 & 8.5 \\
$\quad$ Primary progressive & 3.9 & 8.6 & 0.9 \\
\hline \multicolumn{1}{l}{ No information } & 0.9 & 0.2 & 4.4 \\
\hline
\end{tabular}

and ethnicity. White ethnicity was predominant and the calculation of the sex ratio indicated a greater predisposition of females to contract MS, corroborating most epidemiological studies in Brazil (Table 2).

Analyzing the clinical form of MS, we observed a similarity of the present study with the results from Brasília $(90.6 \%$ relapsing-remitting MS), while in Cuiabá 69.5\% had the relapsing-remitting form.

We found a significant increase in the number of diagnoses since the year 2005 (Figure 3), and most Brazilian studies conducted after the year 2000 also showed a higher prevalence of MS. This increased prevalence can be attributed to the creation of specialized nuclei for the MS patients' care, better training of neurologists in neuroimmunology, and the introduction of MRI services (Figure 3).

In conclusion, we expect to contribute with this descriptive epidemiological study of MS in Goiânia, Goiás, Brazil, and encourage researchers to develop further studies on this disease in different regions of Brazil as there is epidemiological evidence indicating an increased prevalence of multiple sclerosis in areas previously considered to have a low prevalence, as in the case of Brazil in Latin America.

\section{References}

1. Polman $\mathrm{CH}$, Reingold SC, Banwell B, Clanet M, Cohen JA, Filippi M, et al. Diagnostic criteria for multiple sclerosis: 2010 revisions to the McDonald criteria. Ann Neurol. 2011 Feb;69(2):292-302. https://doi.org/10.1002/ana.22366

2. Kurtzke JF. Epidemiologic contributions to multiple sclerosis: an overview. Neurology. 1980 Jul;30(7 Pt 2):61-79. https://doi.org/10.1212/WNL.30.7_Part_2.61

3. Wade BJ. Spatial analysis of global prevalence of multiple sclerosis suggests need for an updated prevalence scale. Mult Scler Int. 2014;2014:124578. https://doi.org/10.1155/2014/124578

4. Instituto Brasileiro de Geografia e Estatística - IBGE. Cidades. 2010 [cited 2018 Sep 4]. Available from: http://ibge-cidades.gov.br

5. Ferreira MLB, Machado MIM, Vilela ML, Guedes MJ, Ataíde L., Santos S, et al. Epidemiology of 118 cases of multiple sclerosis with a 15-year follow-up in the referral center of the Hospital of Restoration, São Paulo, MG, Brazil. of
Pernambuco. Arq Neuropsiquiatr. 2004 Dec;62(4)1027-32. http://dx.doi.org/10.1590/S0004-282X2004000600018

6. Finkelsztejn A, Lopes JS, Noal J, Finkelsztejn JM. The prevalence of multiple sclerosis in Santa Maria, Rio Grande do Sul, Brazil. Arq Neuropsiquiatr. 2014 Feb;72(2):104-6. https://doi.org/10.1590/0004-282X20130216

7. Calmon AB, Pereira F, Marin B, Preux PM, Alvarenga RP. Prevalence of multiple sclerosis in the City of Volta Redonda - Rio De Janeiro, Brazil using the capture-recapture method. Neuroepidemiology. 2016;46(2):88-95. https://doi.org/10.1159/000442471

8. GOIÂNIA. P. Dados gerais. Prefeitura de Goiânia. 2018 [cited 2018 Sep 5]. Available from: http://www4.goiania.go.gov.br/portal/ goiania.shtml

9. Poser CM, Paty DW, Scheinberg L, McDonald WI, Davis FA, Ebers GC, et al. New diagnostic criteria for multiple sclerosis: guidelines for research protocols. Ann Neurol. 1983 Mar;13(3):227-31. https://doi.org/10.1002/ana.410130302 
10. IBM CORP. IBM SPSS statistics for windows: Version, v. 25.0. 2017 [cited 2017 Aug]. Available from: https://www.ibm.com/br-pt/ products? $\operatorname{lnk}=\mathrm{fdi}$

11. Instituto Brasileiro de Geografia e Estatística - IBGE. Censo demográfico de 2015. [cited 2018 Sep 5]. Available from: http://www.ibge.gov.br

12. Pereira AB. Prevalence and incidence of multiple sclerosis in the city of Volta Redonda in the State of Rio de Janeiro [dissertation]. Universidade Federal do Rio de Janeiro, 2015.

13. Pereira ABCN, Lacativa MCS, Pereira FFC, Papais-Alvarenga RM. Prevalence of multiple sclerosis in Brazil: a systematic review. Mult Scler Relat Disord. 2015 Nov;4(6):572-9. https://doi.org/10.1016/j.msard.2015.08.004

14. Callegaro D, Lolio CA, Radvany J, Tilbery CP, Mendonça RA, Melo AC. Prevalence of multiple sclerosis in the city of São Paulo, Brazil, in 1990. Neuroepidemiology. 1992;11(1):114. https://doi.org/10.1159/000110901

15. Callegaro D, Goldbaum M, Morais L, Tilbery CP, Moreira MA, Gabbai AA, et al. The prevalence of multiple sclerosis in the city of São Paulo, Brazil, 1997. Acta Neurol Scand. 2001 Oct;104(4):208-13. https://doi.org/10.1034/j.1600-0404.2001.00372.x

16. Fragoso YD, Brooks JB. The prevalence of multiple sclerosis in the city of Santos has remained unaltered for five years. Arq Neuropsiquiatr. 2012 Jul;70(7):562. https://doi.org/10.1590/S0004-282X2012000700025

17. Fragoso YD, Peres M. Prevalence of multiple sclerosis in the city of Santos, SP. Rev Bras Epidemiol. 2007;10(4):479-82. https://doi.org/10.1590/S1415-790X2007000400005

18. Gama PD, Trigo LX, Andrade CR, Sala CR. Epidemiological study of multiple sclerosis in the city of Sorocaba, Brazil. Arq Neuropsiquiatr. 2004;62(Suppl 1):S13.

19. Lacativa CM, Naylor R, et al. Multiple sclerosis in the city of Rio de Janeiro. LACTRIMS 2012. Abstracts of the Latin American Committee for Treatment and Research in Multiple
Sclerosis. Rio de Janeiro, Brazil: November 2012. Mult Scler J. 2012;18 S5:1850.

20. Lana-Peixoto MA, Frota ER, Campos GB, Monteiro LP; Brazilian Committee for Treatment and Research in Multiple Sclerosis. The prevalence of multiple sclerosis in Belo Horizonte, Brazil. Arq Neuropsiquiatr. 2012 Feb;70(2):102-7. https://doi.org/10.1590/S0004-282X2012000200006

21. Pereira, A. B. C. N. G.; Costa, F. F. C.et al. Epidemiological Study on Multiple Sclerosis and NeuromyelittisOptica in SulFluminense Region in Rio de Janeiro State - Brazil. LACTRIMS 2012. Abstracts of the Latin American Committee for Treatment and Research in Multiple Sclerosis. Rio de Janeiro, Brazil: November 2012. Mult Scler J. 2012;18(5):1837

22. Ribeiro SB, Maia DF, Ribeiro JB, Cardoso FA, Silva C. Clinical and epidemiological profile of patients with multiple sclerosis in Uberaba, Minas Gerais, Brazil. Arq Neuropsiquiatr. 2011 Apr;69(2a 2A):184-7. https://doi.org/10.1590/S0004282X2011000200008PMID:21537557

23. Rocha FC, Herrera LC, Morales RR. Multiple sclerosis in Botucatu, Brazil; a population study. Mult Scler. 2002;8:S412.

24. Dias E, Melges LD. Multiple sclerosis: a prevalence study in the São Paulo Midwestern state. Arq Neuropsiquiatr. 2006;64(1):132. Arq. Neuropsquiatr. 2006;64 (supl 1):132

25. Peruchi MM, Lin J, Lin K, Eckeli AL, Dach F, Leal AG, Machado SCN, Sá PND. Clinical and demographic characteristics of multiple sclerosis in Florianópolis, SC, Brazil. Arq Neuropsiquiatr. 2004;62(supl 2):171.

26. Portela LBBB, Andrade TVF, Borralho WM, Ximenes WN, Dias-Tosta E. Epidemiologic study of the multiple sclerosis in the Distrito Federal, Brazil. Arq Neuropsiquiatr. 2004;62(supl 2):170.

27. Grzesiuk AK, Siqueira HH, Silva NM, Catarino KC, Martins PM [Prevalence of multiple sclerosis in the city of Cuiabá-MT-2007]. O Dendrito. 2008;14(3):35-7. Portuguese. 